'Glauben Sie mir das Wort Blume?' Productive Language Scepticism and Skilful Questioning in the Work of Peter Waterhouse

Author(s): MAURIZIO PIRRO

Source: Austrian Studies, 2004, Vol. 12, The Austrian Lyric (2004), pp. 196-213

Published by: Modern Humanities Research Association

Stable URL: https://www.jstor.org/stable/27944723

JSTOR is a not-for-profit service that helps scholars, researchers, and students discover, use, and build upon a wide range of content in a trusted digital archive. We use information technology and tools to increase productivity and facilitate new forms of scholarship. For more information about JSTOR, please contact support@jstor.org.

Your use of the JSTOR archive indicates your acceptance of the Terms \& Conditions of Use, available at https://about.jstor.org/terms

Modern Humanities Research Association is collaborating with JSTOR to digitize, preserve and extend access to Austrian Studies 


\title{
'Glauben Sie mir das Wort Blume?' Productive Language Scepticism and Skilful Questioning in the Work of Peter Waterhouse
}

\author{
MAURIZIO PIRRO \\ University of Bari
}

Despite being developed within a different gender context, the concept of écriture féminine that was generated in the theoretical approaches of Hélène Cixous and Julia Kristeva is more appropriately applied to the lyric poetry of Peter Waterhouse than perhaps to any other contemporary poetry in German. He shifts the meaning of poetic utterance into a sonorous dimension in which the reader is invited and challenged to share the poet's pleasure in free mental and verbal associations. His work gradually approaches a level of direct, transparent signification that is paradoxically derived not from clarity but from the very diffuseness and indeterminacy of a language that does not straightforwardly express content but releases instead the semantic potential inherent in lyric language for making use of that chora where words exist in a kind of pre-verbal condition, shielded from the falsifications that every speaker risks with every utterance. ${ }^{1}$ Furthermore, he reveals the semiotic structure of poetic communication, to which the reader is drawn by the free-floating movement of a lyric discourse that is not the directly addressed utterance of a clearly defined self but rather takes unexpected directions and pursues every possibility of verbal communication within the polyphonic poetic act. These are the key elements of Peter Waterhouse's poetics, which he has expounded with meticulous precision not only in collections of poetry but also in a range of essays. It can perhaps best be described as a poetics of multiple voices, and has much in common with the Italian philosopher Adriana Cavarero's model of a non-logocentric, subjective, feminine mode of writing. ${ }^{2}$

\footnotetext{
1 The duplicity of lyric language in Waterhouse's work has been traced back to the Romantic concept of the arabesque. See Alexandra M. Kedveš, "IIch vernähte den Himmel mit dem Straßenstück vor dem Haus." Die Arabeske als thematische Form bei Peter Waterhouse', Text + Kritik, 137 (1998), 31-40. For chora (and its Platonic origins) see Julia Kristeva, La révolution du langage poétique. L'avant-garde à la fin du 19. siècle. Lautréamont et Mallarmé (Paris, 1974).

2 See Adriana Cavarero, $A$ più voci. Filosofia dell'espressione vocale (Milan, 2003).
} 
For Cavarero, the voice as the unmistakable sign of human individuality gains relevance from a process of mutual listening, which frees individuals from the hierarchically ordered sentence structure of everyday language and equips them for a purely human encounter with the Other. No loss of subjectivity results from the abandonment of logic that this polyphonic layering entails. On the contrary, the identity of the individual is reinforced in the semiotic process, all the more because the stereoscopic structure of language necessitates the establishment within the speaking voice not only of the speaker but also of one spoken to. The speaker is no longer distinguishable from the listener in the all-encompassing flood of language, but gains instead deeper insight into a self that exists beyond the power-relations that inevitably make themselves felt in normal discourse. The meaning of any verbal utterance is perceptible here only as an ill-defined luminescence, as the final echo of voices long since extinguished, and yet is an unmistakably perceptible appeal to another, comparable perhaps to the inarticulate but nonetheless meaningful babble of a mother playing with her child.

In the same way, the poetics of voices developed by Peter Waterhouse aspires towards the fragmentation of the speaking self which, via the critical destruction of the linguistic conventions that have been unreflectively internalized, will make possible the reconstruction of subjective integrity on a higher plane. This condition is equivalent to an intensified capacity for language itself, attainable only by the individual's commitment to that darker, shadowy aspect of linguistic communication that has been profiled in the theories of écriture féminine. In characterizing Waterhouse's work, écriture feminine is an appropriate term to use insofar as his Sprachskepsis [language scepticism], with its roots in the traditions of Austrian literature, is only rarely manifested in a negative gesture such as the renunciation of any form of verbalization, but instead usually takes the form of a brilliant reactivation of the possibilities of 'saying' based on his astonishing command of the nuances of poetic language. In such a re-energized communicative process, the act of utterance is only one of the innumerable forms that the semiotic chora could have sought out, including the dimensions of silence or even of sheer nonsense.

Waterhouse's position in the Austrian tradition of the critique of language is revealed to be an eccentric one. His goals are not those of Hofmannsthal's Lord Chandos, failing in the face of the inadequacy of verbal understanding and communication; they do not in any way consist in denouncing the subject's lack of heuristic competence. Waterhouse eschews the temptations of hermeticism manifested by Ingeborg Bachmann and is careful not to reduce the reader's perceptive capacity to the mysticism of poésie pure. His poetry never relies on the autonomy of the signifier, not even in the playful manner of the Wiener Schule [Viennese School]. His writing can be described as the happy meeting-point of two fundamentally opposed views of how to preserve the ethical substance of language, those of Karl Kraus and of Paul 
Celan. Waterhouse shares with the former an uncommonly sharp eye for the aesthetic and moral damage inflicted by the falsification of language for reasons of prejudice and partiality. A memorable example is the way in which the emptiness of political rhetoric is exposed in the 'Gedicht.Roman' [Poem.Novel] entitled Sprache Tod Nacht Außen [Language Death Night Outside] using the endless repetition of hollow terms such as 'consensus' and 'reconciliation' that are habitually misused in the language of those in power. ${ }^{3}$ Celan was the subject of Waterhouse's doctorate, and in aspects of Celan's poetics, such as his sensitivity to the multiple meanings of poetic language and the refined techniques of textual construction, Waterhouse discerns a necessary supplementation of Kraus's typical concern with the public and political relevance of language. He reads these features of Celan's work as the transcriptions of psychic processes that are determined in a completely subjective manner, but nonetheless enable the sensitive reader to achieve new insight into the alogical depths of his own interiority via the endlessly protractable game of minute displacements of word and emphasis. ${ }^{4}$

Waterhouse aims quite consciously at surmounting the merely rational or logical construction of subjective identity by overlaying or superimposing unfamiliar voices. ${ }^{5}$ Ringing out, hypnotic and fascinating, they guide the individual towards an apprehension of a realm of spiritual truth where mankind maintains its humanity, insofar as it is prepared both to confront the external world and to recognize itself in everything external. In Waterhouse's poetics, these voices are charged with 'verfremden' [alienating / making strange] the individual by requiring a form of self-contemplation from a quasi-external perspective. Man must be outside of himself in order to be able to perceive the underlying interrelatedness of existence as a whole - a process that is inconceivable using the traditional means of logical thought. ${ }^{6}$ The following extract from the 'Gedicht.Roman' shows how Waterhouse uses a poem by Celan in an attempt to establish his poetics of voices

${ }^{3}$ Peter Waterhouse, Sprache Tod Nacht Außen. Gedicht.Roman (Reinbek bei Hamburg, I989), pp. $48-52$.

${ }^{4}$ Waterhouse has himself contributed significantly to the interpretations of this game. See Peter Waterhouse, 'Un, an, atmen, Deutschland. Versuch über Paul Celans Gedicht "Wolfsbohne", Text + Kritik, 53/54, 3rd edn (2002), 38-47.

5 Jürgen Engler has written of the 'entfestigende Wirkung' [de-consolidating effect] of the 'poem without meaning': 'Phantastik des Gewöhnlichen oder Stifter on the road', Neue deutsche Literatur, $44 / v$ (1996), $149-54$ (p. 152). It must be stressed, however, that Waterhouse is not practising anything like a poetics of the absurd. His variant of écriture feminine corresponds to Terry Eagleton's view that 'the semiotic is not an alternative to the symbolic order [...]: it is rather a process within our conventional sign-systems, which questions and transgresses their limits'. Literary Theory. An Introduction, 2nd edn (Oxford, 1996), p. 164.

${ }^{6}$ For a particularly pertinent discussion of this point, within the context of a reading of Waterhouse's work as 'Sabotage an Sinn- und Satzzusammenhang' [sabotaging the coherence of sentences and meaning], see Christian Döring, 'Jedes Wort eine Sprache. Über den Lyriker Peter Waterhouse', Neue Rundschau, I02/iii (1991), 163-65 (p. 164). 
synaesthetically on the basis of differences between processes of argumentation and intuition:

Ich sah das Stimmliche anders da sein als das Sprachliche. Ich sah die Stimme etwas nicht sprechen können. Ich sah die Stimme in das Flüssige gebracht sein. Ich sah die Stimme in das Grün des Flüssigen gebracht sein. Ich sah die Stimme ins Unfaßlichste gebracht sein. Ich sah die Stimme als liquid, geschmolzen, durchsichtig. Ich sah das Gedicht die Stimmen ins Bild des Wassers übersetzen. ${ }^{7}$

[I saw the vocal as existing differently from the linguistic. I saw the voice unable to speak something. I saw the voice brought into the fluid. I saw the voice brought into the green of the fluid. I saw the voice brought into what was least tangible. I saw the voice as liquid, molten, transparent. I saw the poem translate the voices into the image of water.]

Under these circumstances, a fixed orientation of the lyric persona is clearly impossible. The ' $\mathrm{I}$ ' is engulfed by the plethora of linguistic variations and the interrupting voices - which initially give the reader the feeling that language has developed a will of its own against which the individual speaker is powerless - only to re-emerge as a provisional, ever-shifting vanishing point at which all the lines of poetic utterance converge. That is the case until it becomes evident that convergence is an illusion, as the myriad languages of the countless forms of 'you' flow from the mouth of this insubstantial ' $\mathrm{I}$ ' and are reflected in its protean surface. The 'isomorphic unity' of language and landscape in Waterhouse's poetry has rightly been stressed, ${ }^{8}$ but it should be added that this can be traced to a long-standing tendency in Waterhouse to observe and represent poetic discourse and its traditional polarities (the speaker, the reader) from a critical distance. This makes the literary text into a platform or a stage on which to test the fitness for action of the externalized components of lyrical discourse. ${ }^{9}$ Waterhouse's poems are imbued with the pleasure of staging, which both lends theatrical credibility to the way in which they communicate and offers the reader points of orientation on the way to a careful comprehension of the text. In assessing these texts there is a difficult balance to be struck in the face of the surprising fact that an explicit awareness of the artificial character of the poetic utterance in Waterhouse is deliberately concealed by a high degree of artistic rigour, which only allows it to come to the surface in rare transitional moments.

For a gifted translator such as Waterhouse, who has not fought shy of poets such as Gerard Manley Hopkins and Biagio Marin, known for their

\footnotetext{
7 Waterhouse, Sprache Tod Nacht Außen, pp. 85-86.

${ }^{8}$ Luigi Reitani, 'Durchlässige Textlandschaften. Zu einer poetischen Konstante im Werk von Peter Waterhouse', Text + Kritik, 137 (1998), 68-76 (p. 68).

9 Erk Grimm rightly identifies one of the most characteristic features of Waterhouse's work as the way in which 'the poem makes a clear distinction between the rules of everyday language and the eccentricity of poetic writing'. Erk Grimm, 'The Abjectum: Peter Waterhouse's Reappropriation of Hölderlin and the Poem-In-Progress', in After Postmodernism. Austrian Literature and Film in Transition, ed. by Willy Riemer (Riverside, CA, 200o), pp. 235-63 (p. 244).
} 
concise and intellectualized style, the concept of 'Übergang' [transition] is important both poetologically and critically. On one level the translator ensures that the texts complete a transition into new texts without merely being straightforward reproductions of content in a new linguistic garb. Waterhouse sees the activity of translation as a magical act of rediscovery, based not on the transmission of signs into a new semiotic system but on the alienation of these signs via the revivification of what is strange about them and remains suppressed in simpler, more functional everyday discourse. ${ }^{10} \mathrm{It}$ is not a question of transcending the differences between individual languages in order to achieve universal comprehensibility but of sensing the secret relationships that bind together all spoken words and of calling into existence the hidden potential of a particular language. Faced with a difficult translation from Italian, Waterhouse found himself initiated into the mystery of the profound unity of all utterance: 'In den übersetzten Zeilen erschien die deutsche Sprache. In Übergangsaugenblicken erschien sie als Sprache ohne Nationalität. Der Plural des Wortes Sprache blitzte auf. Im Aufblitzen des Plurals war jedes Wort eine Sprache' [The German language appeared in the translation of those lines. In moments of transition it appeared as a language without a nationality. The plural of the word language flashed out. In the flash of the plural every word was a language]. ${ }^{11}$ Elsewhere he explains: "Übersetzen: nicht "aus dem Italienischen" ins "Deutsche" übersetzen, sondern eine italienische Sprache oder eine fremde Sprache in der deutschen finden, das ungesprochene Deutsch vielleicht, das unbekannte, das vergessene' [Translation: not translating 'from Italian' into 'German', but finding the Italian language or a strange language within the German language, an unspoken German perhaps, an unknown one or a forgotten one]. ${ }^{12}$ Knowing that language-boundaries are only the product of a falsification that we are accustomed to use as protection against the threatening experience of being beyond ourselves, Waterhouse decisively rejects the use of language as an instrument of power for the purposes of transfiguring the here-and-now. The dangers of instrumentalizing language in this way are kept in check in Waterhouse's work by the manner in which language itself is constantly being dynamized, thus allowing no restricted community to lay claim to it. An apolitical stance such as this is highly characteristic of Waterhouse's work, expressed in the subject's need for untrammelled freedom of movement and overriding fear of paralysis. In the 'Gedicht.Roman' we read, 'ich stellte mich nicht der Machtfrage. Ich gehörte keiner Gruppe

\footnotetext{
${ }^{10}$ In a lecture on poetry by Hamburger and Pessoa Waterhouse describes translation in this spirit as 'eine Art und Weise, Unwahrheiten zu finden. Fast ist die Übersetzung ein Synonym für die Unwahrheit' [a means of discovering untruths. Translation is almost a synonym for untruth]. Peter Waterhouse, 'Die Unwahrheit', die horen, 47 (2002), I15-29 (p. I15).

11 Waterhouse, Sprache Tod Nacht Außen, p. 56.

12 Peter Waterhouse, Die Geheimnislosigkeit. Ein Spazier- und Lesebuch (Salzburg and Vienna, 1996), p. 6 r.
} 
an. Ich organisierte mich nicht. Ich floß als unterirdischer Strom. Ich war rastlos. Ich war unnachgiebig. Ich behauptete nichts von mir. [. . .] Ich erkannte das Offene' [I did not surrender myself to power. I did not belong to any group. I did not organize myself. I flowed like a subterranean river. I was restless. I was intransigent. I did not make claims about myself. I understood openness]. ${ }^{13}$

There is an even more important aspect of the notion of transition in Waterhouse's lyric poetry, which is connected with the fluidity of the boundaries of individual identity and is not dissimilar to the way in which the concept 'Übergang' was used half a century before by Max Kommerell (1902-1944), a theorist who has much in common with Waterhouse. ${ }^{14}$ The 'pregnant moment' in Waterhouse's poetry (to use a term from Weimar Glassicism's debate about art) coincides with the dissolution of the integrity of the individual in the process of a transition into the dimension of the Other. This transition operates on three levels: the self can unite with the person confronting it, or it can merge with the things that surround it, or it can return to the sources of language itself and dissolve peacefully into the totality of the sayable. What matters is that the subject recognizes itself as something foreign, something outside, as a thing amongst other things. Herein lies the disturbing tone in the work of this poet - what might be called the 'Waterhouse sound' - consisting of an unremitting tension between the subjective nature of poetic utterance and the objectifying content of that utterance. Such a tension challenges the reader to an immensely playful form of aesthetic participation. The author's preference for paratactic structures exactly corresponds to his perpetual striving to represent the world not from a superior vantage-point but from the same level as even the least significant objects, which, in their apparent valuelessness, hold the key to understanding the profound language that unites everything that is.

Waterhouse has his own poetic ritual of naming, reminiscent sometimes of Hofmannsthal and Rilke, but distinctive because, despite a certain solemnity in its practice, the poet possesses no demiurgic power whatever. His naming of things is not the same as creating them anew; it is the subject itself that is reborn through its humble reification in the act of meeting the Other. In Peter Waterhouse's poetry man is both within and beyond himself, and in swinging between these two states experiences an absolute and semi-mystical sense of openness. As if before a magic mirror, man recognizes the constant presence of death within life:

Wenn der Tod kam, füllten alle die Hände mit Kirschen. Wir pressen das Rote hervor, es tropft

\footnotetext{
${ }^{13}$ Waterhouse, Sprache Tod Nacht Außen, p. 99.

14 See the contributions to Max Kommerell. Leben - Werk - Aktualität, ed. by Walter Busch and Gerhard Pickerodt (Göttingen, 2003).
} 
von den Händen herab. Jeder sprach: Aber der Tod ist außen. Aber innen sind wir (unterwegs auf dem inneren Umweg). In die Stille wurde gefragt: Wer spricht? Der Hörende ist immer der Äußere (auf äußeren Wegen geht solcher). O, wie tief innen bin ich.

[...] Wir leben zwischen den eigenen Gesten. Innen? Aber die Gesten sind außen. ${ }^{15}$

[When death came, everyone filled their hands with cherries. We squeeze the red out, it drips down from our hands. Everyone spoke: But death is outside. But we are within (travelling on the inner detour). Into the silence the question was asked: Who is speaking? The one hearing is always the one outside (such a one walks on paths outside). O, how deeply within I am. We live between our own gestures. Inside? But the gestures are outside.]

The blurring of the boundaries between inside and outside, inner and outer, necessitates a language that helps the individual overcome the limitedness and restrictedness of his inner existence and helps him achieve an intuitive understanding of the universal language that permeates the entire world. This is the basis for Waterhouse's characteristic 'Sprachgebärde' [linguistic gesture] - another potential point of comparison with Kommerell. In gestures that are devoid of intentionality and only meaningful to empathetic participation, subjective interiority and the outer phenomenal world are the practitioners of a common language, the same language that enables things in the world to communicate with each other. In an interview with Martin Kubaczek appended to the collection Blumen [Flowers], Waterhouse describes his vision of a 'parataktische Landschaft' [paratactic landscape], 'eine, wo die entgegengesetzten Dinge gleichzeitig möglich sind, eine, in der es keine übergeordneten oder untergeordneten Strukturen geben könnte' [one in which opposites are simultaneously possible, one in which structures of precedence or subordination could not exist]. ${ }^{16}$ This is the landscape in which the totality of the individual is only imaginable as the combination of gestures objectivized in an almost theatrical fashion as if from the perspective of someone outside looking in - 'Wer geht hier | Ich?' [Who goes there, me?] ${ }^{17}$ - and in which miraculous unions of opposites can be achieved. ${ }^{18}$ Waterhouse sees mankind's capacity for perception as following spatial, scenic principles: 'Es sind nicht Dinge, die wir wahrnehmen, es sind Landschaften. Die Augen sind Landschaftsbeobachter, Parataxisschauer,

15 Peter Waterhouse, Menz (Graz, 1984), p. 57.

${ }_{16}$ Peter Waterhouse, Blumen (Vienna and Bolzano, 1994), p. 40.

17 Peter Waterhouse, Prosperos Land (Salzburg and Vienna, 200I), p. 6r.

${ }^{18} \mathrm{See}$ in this context the interesting reflections by Martin Kubaczek: 'Sprachliche Topographie. Zur Konzeption des poetischen Raums bei Peter Waterhouse', Text + Kritik, I37 (1998), 53-67. 
Umgebungsseher. [...] Wahrnehmung ist landschaftlich. Erinnerung ist landschaftlich' [It is not things that we perceive, it is landscapes. Our eyes are observers of landscapes, watchers of parataxis, seers of surroundings. Perception is scenic. Memory is scenic]. ${ }^{19}$ Analogously, the objective world, the world of technology, obeys the same scenic imperatives:

Das blinkende Licht, wo die Straße das Gleis überquert. Diese Blume scheint im

Wind

bewegt, unstet zwischen Schatten und Lichtreflex.

Die Neonlampen, neun Uhr morgens, in der großen Halle, die Gewächshausblumen.

[...] Im Innenraum des Wagens ein blütenrunder Tachometer und sein weiches Grün.

[...] Zigarettenautomat, eine artifizielle Blume, ähnlich schön wie eine Aster.

[...] Verkehrstafel für die Autobahn: die Himmeldotterblume. ${ }^{20}$

[The blinking light, where the road crosses the track. This flower seems to be moving in the wind, restlessly shifting between shadow and light reflex. The neon lamps, at nine in the morning, in the atrium, the hot-house flowers. In the inside of the car a tachometer round as a flower in bloom and its soft green. A cigarette machine, an artificial flower, beautiful like an aster is. A traffic sign for the motorway: heaven's buttercup.]

In its dual identity as both something sunk in the depths of its interiority and at the same time something observing itself from the external stance of the Other, the objective, the subject of these poems is displaced ever more into the outside world - to the point where the possibility of unity with the phenomenal world emerges, on condition that the language spoken is without intention and a-semantic. The giddy round-dance that the author engages in as he spins every conceivable articulation of the narrative ' $I$ ' in various parts of the 'Gedicht.Roman', ${ }^{21}$ can be seen as the attempt to free subjective experience from the hegemony of all-encompassing, logocentric reason and to re-orientate it such that the individual can experience himself as re-born in the process of reification. It is on this level - where mankind can disregard all forms of generally intelligible speech and, secure in the sense of common objectivity, entrust himself wholly to a new sense of his own body - that the engagement with the 'You' takes place. This engagement does, however, promise a point of repose in what is for

\footnotetext{
19 Waterhouse, Die Geheimnislosigkeit, p. I43.

20 Peter Waterhouse, Verloren ohne Rettung (Salzburg and Vienna, I993), pp. 24-25.

${ }^{21}$ A dance that Waterhouse described thus, in conversation with Gert Neumann: 'In dem Buch wird so oft "Ich" gesagt, daß es jedem Leser so ergeht, daß das Ich sich desintegriert und eigentlich das Folge-Ich des nächsten Satzes schon ein anderes ist als das des vorherigen' [In this book the word ' $I$ ' is uttered so often that every reader feels that the ' $I$ ' is disintegrating and that the succeeding 'I' of the next sentence is a different one from the one before]. See 'Gespräch mit Gert Neumann und Peter Waterhouse', in Zettelwerk. Gespräche zu einer möglichen Form, ed. by Lucas Cejpek (Vienna, 1999), pp. 107-17 (p. 115).
} 
Waterhouse an almost phenomenologically conceived 'Geworfenheit' [thrownness], but one that is frequently also tinged with Existentialism:

Nachdem alles losgelassen war, berührten wir uns. Berühren heißt: Wie

hast du losgelassen? I. Antwort: Ich habe es getan

in der unbeantwortbaren Weise. 2. Antwort:

Ich fiel aus der Höhe der Antwort. Drittens:

Alles weitere fält unter die dritte Antwort. ${ }^{22}$

[After everything had been let go, we touched. Touching means: How have you let go? Ist answer: I did it in the unanswerable way. 2nd answer: I fell from the height of the answer. Third: everything else falls under the third answer.]

Careful questioning produces the meeting with the Other, but there is no immediate response. As long as the questioning fails to adapt itself to the many-layered plurality of the world, the meaning of the question is irrevocably lost in the stony silence of the creatural:

[...] Wir sind

keine Antwort (wir sind fast

ein Hut, fast ein Schrank, fast eine Birne auf Erden)

auf welche Frage? ${ }^{23}$

[We are not an answer (we are almost a hat, almost a cupboard, almost a pear on earth) to which question?]

\section{II}

The next step is to analyse the poetological relevance of questioning in Waterhouse's poetry in the context of the reified, concrete language that the poet conjures up as a semiotic alternative to the realm of pure reason. ${ }^{24}$ Relevant here is Waterhouse's impression, which he has admitted to in an essay on translation, 'daß der Inhalt etwas ist, das der Sprache fast fremd ist und daß es einen viel feineren Inhalt gibt, der als Inhalt nicht leicht zu erfassen ist' [that content is something almost alien to language, and that there is a much finer form of content, which is not easy to grasp as such] ${ }^{25}$ Reading Waterhouse, one is occasionally troubled by the suspicion that certain stylistic features are liable to become part of a self-indulgent rhetoric that over-stylizes and reduces the force of the linguistic argument. This was

${ }^{22}$ Peter Waterhouse, passim (Reinbek bei Hamburg, 1986), p. 34 .

23 Waterhouse, Menz, p. 66.

${ }^{24}$ As, for example, in the conversation with Martin Kubaczek, where Waterhouse imagines 'ein Bereich zwischen Aufklärung und Nicht-Aufklärung' [a realm between enlightenment and non-enlightenment], of which he makes use for his poems (Waterhouse, Blumen, p. 58). See also the challenging essay by Hartmut Kasper, 'Meister Peter, Mystiker', Text + Kritik, 137 (1998), $25-30$.

${ }_{25}$ Peter Waterhouse, 'Die Übersetzung der Worte in Sprache', in Peter Waterhouse, Ulrike Draesner and Barbara Köhler, : to change the subject (Göttingen, 200o), pp. 5-10 (p. 5). 
certainly the charge laid at his door - and rightly — when he published his sparse, laconic comments in a volume alongside extended and more systematic poetological reflections by Dürs Grünbein and Brigitte Oleschinski. ${ }^{26}$ Nevertheless, amongst the range of stylistic features, it is impossible to overlook the immense heuristic value that Waterhouse attaches to the process of questioning and to his virtuosic distribution of question-marks on the surface of the text, amongst other stylistic devices available to him. What is at issue here is a questioning, in both form and substance, not merely of current intellectual structures and their taxonomic categories but of fundamental modalities of human perception. It is less the 'what' than the 'how' of individual and collective experience that is addressed by the untiring repetition of questions that the author asks himself and the reader at every turn. The poetic utterance is constantly interrupted - almost to the point of what might be called a verbal 'short-circuit' - by questions relating to its content as well as to the feelings and thoughts of the writer, which are comprehensible to those outside only intuitively or empathetically. These interruptions are at first sight, and at first hearing, somewhat off-putting. The reader may fail to appreciate their productive effect and be inclined instead to attribute them to the peculiar rhythms of the text, rhythms that the poet - using a technique that has neatly been described as 'Selbstaufhebung des eben Gesagten' [what has just been said rescinding itself] ${ }^{27}$ - is producing by means of oscillations between positive assertion and disillusioned negation. Or, less generously, the reader may put them down to the author's latent indecisiveness or communicative insufficiency. ${ }^{28}$

Once we move on, however, from the linear, logical or causal development of thought to the images and the musicality of the poetry, seeing in the latter a structural principle that is as important to the text as its communicative substance, then it is possible to establish the intimate reciprocity of form and content in Waterhouse's work. Then, too, it becomes evident that the moments when the text is rendered opaque by an often confusing plethora of questions are important cruxes at which content and musicality most clearly meet. From this perspective it is not coincidental that such textual cruxes are the most illuminating for the development and understanding of Waterhouse's principal concern, Sprachkritik. There is, it seems, critical consensus that the aim of Waterhouse's 'minimalistische Poetik' [minimalist

\footnotetext{
26 See Dürs Grünbein, Brigitte Oleschinski and Peter Waterhouse, Die Schweizer Korrektur (Basel, 1995). Waterhouse's essay is entitled 'Gedichte und Teillösungen' [Poems and Partial Solutions], pp. $48-65$.

${ }_{27}$ Martin Kubaczek, 'Form als Utopie? 8 Möglichkeiten, zu den Menz-Gedichten von Peter Waterhouse (nicht) zu sprechen', manuskripte, I29 (1995), I2I-30 (p. I2I). I am greatly indebted to this article's thought-provoking account of the structures of questioning in Waterhouse's poetry.

${ }^{28}$ This is the response of Harald Hartung in 'Guten Tag: Gedicht. Fünf neue Lyriker', Merkur, $4 \mathrm{I}$ (1987), $147-53$, who interprets the frequent questions in Waterhouse as remaining 'beim Disparaten der Wörter' [at the level of the disparateness of words] (p. I49).
} 
poetics], ${ }^{29}$ or at least its most clearly identifiable core, lies in the consistency with which he investigates one of the most crucial questions of twentiethcentury literature, that of where the boundaries of language are laid, paying close attention to typical manifestations of our own fin de siècle. Against the background of the poetics of voices discussed above, I shall attempt in what follows to explain the role of the questioning counter-voice, exploring in particular the variety of different functions that the act of questioning assumes in a poetics such as Waterhouse's.

On one level, the relevance of question-marks in Waterhouse's poetry is strictly poetological. Relativizing a statement by alluding to the truth-content of a completely opposed eventuality may appear disillusioning, but may well assist the reader in coming to a more differentiated comprehension of the text and assist the author in fruitfully interrogating the stylistic or substantial stringency of the utterance. In his first collection, Menz, Waterhouse makes use of disturbing questions to 'brake' the flow of lyrical expression. These are carefully placed at important points (usually where one would expect a pause or anticipate a clarification of the intended meaning), and do not so much rescind what has just been said as thematize it critically and with a degree of sceptical irony. At the beginning of Menz, placed with unmistakably programmatic intent, the perfectly straightforward questioning in the following quotation is intended to make apparent the ever-present nature of the poetic voice, which is stereophonically able both to claim something and to doubt it:
Aus allen erdenkbaren Gründen (wie bitte?)
musizieren deine Hände. Du sitzt
wo? Im Innern der Geige. Jeder fragt:
ist das sein Haus? Wo der wohl die Beine lagert? Im Hals
oder Bauch oder in einem Dritten? ${ }^{30}$

[For all conceivable reasons (excuse me?) your hands make music. Where are you sitting? Within the violin. Everyone asks: is that his house? Where I take it he puts his feet up? In the neck, or the belly, or in a third place?]

The questions here operate as a means of interrupting the lyrical continuity of the text and are intended to subject the individual components of the sentence to stylistic and semantic scrutiny. It is not only that the opening sentence is exposed in its limitedness, which re-activates the reader's attention, moving beyond initial irritation to produce a great degree of tension; more important for the author's linguistic strategy is the fact that the gently smiling relativization affects not only the solemn gesture of the speaker on the threshold of that holy and institutionalized locus of intellectual

\footnotetext{
29 The phrase is used by Felix Philipp Ingold, 'Weiterschreiben. Beispiele heutiger Autorenpoetik', manuskripte, 132 (1996), 97-104 (p. 99).

30 Waterhouse, Menz, p. 9 .
} 
communication, the book, but the initiation of the reader's literary memory, too, which prevents a simple, passive reception of the text. As soon as the educated reader is prompted to recall examples of 'high' poetic diction firmly embedded in the culturally conditioned memory, the interest in the text is displaced at once into vague literary memory: there are faint echoes of Goethe's 'Über allen Gipfeln ist Ruh' [Over all the hill-tops it is still], together with a little of Brecht's 'Die Seeräuber-Jenny' [Pirate Jenny] from Die Dreigroschenoper [The Threepenny Opera]. The reader is exposed to sharp parody that targets both the stance of the poet and the attitude of the reader. By impeding the lyrical flow, reducing it cleverly to its components, Waterhouse intimates to the reader the necessity of taking part in the construction of the meaning by listening closely, shutting out everything that does not have direct relevance to the voice of the poet.

However, fading out all links with past literary texts can only happen after those very links have been activated, which means that for Waterhouse the liberating aspect of art in the humanist mould is not based on the absolute rejection of literary tradition but on the reader's consciousness of the need for an active and critical interrogation of this tradition. Ironically inspecting the eloquence of the stylistic repertoire of poetry makes it possible for Waterhouse to cement the reader's and his own relationship to the hermeneutic circle, such that both, in different ways, contemplate the gradual, plastic unfolding of the text as if watching a flowing stream.

An intuitive confrontation with fragments of the language of tradition leads Waterhouse to externalize the coherent unity of a poetic text, which can be rendered operational again in the present and in the pursuit of subjective life. A simple question taken from the realm of harmless, unreflective everyday language can dramatically reveal the critical condition of worn-out poetic language and at the same time proclaim the revitalization of this very language:

$[\ldots]$ ich fliege weit fort

aus einem vorenthaltenen Menschen, geradewegs vor eure Kanonen

gleichteils zersträubt, gleichteils das höchste Gebirge

schau mir nach, ich schau nach dir

ein Mond gebracht um den Mond, oder wie soll ich es sagen ${ }^{31}$

[I am flying far away out of a withheld human being, half atomized straight in front of your cannons, half the highest mountain, watch me, I'm watching you, a moon deprived of the moon, or how should I put it?]

The fact that the verbal flow is pulled up despite the forward-moving energy of the text is far from being an attempt to distort the lyrical utterance or make it inauthentic. Waterhouse's play with language is profoundly serious and consists in conjuring up a much more significant poetic unity from the

31 Peter Waterhouse, Das Klarfeld Gedicht (Berlin, r988), p. 25. 
collapse of one that relied on logical coherence. This more significant unity sees an opportunity in the loss of tradition much like the one Schiller attributed to the sentimental poet; it is one that will arise not from immediate possession but from a critical investigation of tradition and its language.

The work of displacing the lyrical subject into a sphere in which it is to function as both speaker and spoken-to is difficult and highly refined. It makes use of forms of expression linked to the act of questioning in as much as it is precisely via questioning that an imaginary dialogue can be constructed, whose task it is to make from the hypnotic chains of words extending through the texts a clearly contoured concretion of utterance. The counter-voice that interferes abruptly offers a perspective on the sentences uttered by the soliloquizing ' $I$ ', relativizing them at the same time:

Der Husten ist in diesen Tagen weit verbreitet. Das besagt wenig. Was besagt in dieser Stadt viel? Man kann anfangen auf den Straßen: Die Wagen und Bahnen sind schnell unterwegs. Die Schilder werden gelesen. Wer geht oder rennt aus dem Tor? Die Hustenden und die anderen. ${ }^{32}$

[There are a lot of coughs going around nowadays. That doesn't mean much. Was does mean anything in this city? You can begin on the streets: the cars and trams move rapidly on their way. The signs are read. Who is walking or running out of the gate? Those with coughs and the others.]

The visionary image of a coughing city occupies the consciousness of the reader via a double process of objectivization. ${ }^{33}$ On the one hand, the scenes depicted are made more concrete with the help of mimetic touches; the alienating impression conjured up by the scenario of a city full of people coughing is reduced by the (banal and anything but worrying) observation that the cars in this city are driven quickly, with due attention being paid to the road-signs. On the other hand, however, the questions posed by an indeterminate alternative voice to that of the 'I' establish a perfectly normal dialogic relationship that serves principally to enhance the tangibility and concreteness of what is being said and thus bring it closer to the reader. From the introverted domain of an ' $\mathrm{I}$ ' expatiating in monologues is developed an open stage on which the truth, made accessible in spite of the clumsiness of human perception, is rendered objective, clear and transparent. And yet it is buried ever deeper by each new question, because its ultimate sense lies not in searching questioning but in pure silence:

«Was hast du zu sagen?»

Ich halte Abstand.

«Wovon Abstand?»

32 Waterhouse, Menz, p. 21.

33 For brief but insightful remarks on the city in Waterhouse's poetry, see Luigi Reitani's afterword, in Luci Lune Luoghi. Antologia della poesia austriaca contemporanea, ed. by Luigi Reitani (Milan, I999), pp. 59I־95. 
Von der Wahrheit.

«Was ist Wahrheit?»

Das Gefragte.

«Du fragst nichts?»

Nein.

«Was willst du mir hier zeigen?»

Die Mitte.

«Die Mitte wovon?»

Ich weiß es nicht. ${ }^{34}$

['What do you have to say?' I am keeping my distance. 'Distance from what?' From truth. 'What is truth?' What has been asked. 'Are you asking nothing?' No. 'What do you want to show me here?' The centre. 'The centre of what?' I don't know.]

By way of summary one might say that questioning extends the semantic spectrum of the poem in that the imaginary interlocutor (the 'you') relativizes the poetic utterance and makes concrete the linguistic context within which the operation of the lyric is taking place. This dialogic development, which also creates a theatrical effect, gives the field of language a measure of transparency that allows the reader to exercise a degree of control over the coherence of what has been written. In the questioning, however - as the passage cited above makes clear - there is only a barely comprehensible echo of the truth. What is revealed is merely an impenetrable outer shell, whose content can only be fully apprehended in a mystical experience. Nonetheless, for Waterhouse the act of skilful questioning remains the privileged heuristic path for breaking out of the confines of his subjectivity and meeting the Other in the shared recognition of their mutual alienation which is at the same time the only possible perspective for self-understanding. The lack of information about the real relative positions of ' $I$ ' and 'You' in the linguistic field dissolves all individual polarity and simultaneously triggers a fascinating intermingling of speaker and listener. Some of the most rhythmically effective lines from a poem in passim show how the perspective of the speaker is gradually reduced from the depiction of external details that the responses of the other voice expect to the mere contingency of naked corporeality:

Ein wenig planlos. Wie gefällt ihnen meine Krawatte?

Wer hat die rote Krawatte mir umgebunden? Wo ist der Himmel?

Warum habe ich sehr dumme Augen? Zählen Sie meine Finger?

$[\ldots]$

Wer erstickt, wo wir atmen? Lunge.

Warum macht die Sonne meine Nase rot? ${ }^{35}$

[A little aimless. How do you like my tie? Who tied the red tie for me? Where is the sky? Why do I have very stupid eyes? Will you count my fingers? Who is being stifled where we are breathing? Lung. Why does the sun make my nose red?]

\footnotetext{
${ }^{34}$ Waterhouse, Verloren ohne Rettung, pp. 98-99.

35 Waterhouse, passim, p. 94 .
} 
Questions in Waterhouse may also vary a descriptive sequence via the lifting of mimetic procedures in that the introduction of a new argument in poetic speech makes the reader aware of the possibilities of freely available alternatives to the experiences that the lyric ' $\mathrm{I}$ ' is describing - 'Wir | waren hell. Gab es auch Schatten? Ja' [We were light. Were there shadows, too? Yes]. ${ }^{36}$ We are here getting closer to the true metapoetic function of questioning, which is linked to Waterhouse's distinctive interests in Sprachkritik - manifest in the tendency to make explicit the logical and perceptive tensions within the construct of the text by means of the linguistic concretion of polarities that are brought forth by these tensions. The questions asked in a poem can, in fact, make the poetic image more precise using an allusion to what has not been said. But it is not only what has been suppressed that allows us to gauge the semantic intensity of Waterhouse's poetry. Rather it is the virtual, undeveloped areas of content that are conjured up by a question and in particular by the elements associated with the question (the speaker's emphases, gestures, facial expressions), which enrich the text with a decisive illocutionary dimension and help the reader to achieve a more complete encounter with the text - in the sense of a sensitivity to what is individual about the speaking voice, a feature that is so marked in Waterhouse's écriture féminine. The structure of the lyric sentence thereby receives a dynamic impulse which intimates the virtual infinity of the possibilities of expression. The increased speed of these mental associations also affects the reader, who is expressly and insistently called upon to extend the time of his own textual reception at the moment of hearing in such a way that all the images not taken account of by the author can nonetheless be conjured up.

[...] Sie stechen mit Schaufeln, sie graben

die unterste Lage hervor. Wir erzählen (wie? wie? wem? wem?). ${ }^{37}$

[They are stabbing with shovels, they are digging out the bottom layer. We are telling (how? how? who? who?).]

This, one of the many examples yielded by the question-rich collection Menz, can be complemented with two lines from Das Klarfeld Gedicht:

die Stadt will zur Stadt, was liegt dazwischen darum, darüber, darin? ${ }^{38}$

[the city wants to go to the city, what lies between, around, above, within?]

In contrast to a function such as this, which magnifies the sphere of what has been said, questions can also have a dissecting function. The multiplicity of

36 Waterhouse, Menz, p. Io.

37 Ibid., p. $3^{8 .}$

38 Waterhouse, Das Klarfeld Gedicht, p. 16. 
the possible alternatives that are to be weighed up by the subject when speaking, and that are implied by the various different answers, can, as it were, 'dismantle' poetic utterance such that only fragments remain. This is the case in the most inarticulate of Waterhouse's poems, those in which the author seems to abandon any coherence whatever and to entrust himself and his readers to the power of the unfettered imagination. The results of this play with language and ideas are figures of purely imagistic suggestiveness, freed from all possible symbolic background in the perfectly indifferent anticipation of the interpretative skill of the reader, who is at liberty to do as s/he will with the fractured textual surface:

\author{
Wir werden hörbar. Wie lange \\ hat das Warten gedauert? Ging etwas \\ verloren in der Stille? Keiner versteht \\ das Schwankende besser. Gut war weniges. Spät \\ ließen wir es an uns liegen. War das \\ ein Irrtum? Nein. Wie wir staunten! Das also \\ waren wir. Und weiter? ${ }^{39}$
}

[We are becoming audible. How long has the wait lasted? Was something lost in the silence? No-one understands hesitations better. Good was little. At a late stage we let it lie with us. Was that a mistake? No. How we were amazed! That was us, then. What next?]

This Austrian poet's most distinctive metapoetic use of question-marks coincides with the more or less explicit thematization of his '(Ver)Zweifeln' [doubt and despair] about being able to express communicable content in speech that at the same time makes possible a response from those addressed. In the act of questioning it is often the case that the absolute falsehood of every possible answer is revealed by the way in which the content present in the question makes one aware of an unexpected perspective that annihilates all hope of any heuristic value in questioning itself. By means of questioning and the lack of logical answers the legitimacy and the heuristic potential of poetry become the subject of discussion. This is revealed in a collocation of opposite polarities that can no longer be rationally understood, in the abandonment of all forms of dualistic thinking - as evinced by one of Waterhouse's best known and most disillusioning lines: 'Ist es still? Ja. Nein' [Is it quiet? Yes. No]. ${ }^{40}$ Alternatively, it may be revealed in the radical abolition of the content of the answer whilst maintaining the presence of the imagined interlocutor:

39 Waterhouse, Menz, p. I4.

40 Ibid., p. 27. And the next poem has: '[. . . Sind Landschaften? Ja. Nein. I Sind Reisen? Ja. Nein. Sind Sterbende? Ja. Nein. Sind die Böden fort? Ja. | Nein' [Are there landscapes? Yes. No. Are there journeys? Yes. No. Are people dying? Yes. No. Have the floors gone? Yes. No] (p. 28). 
a: Welche Dunkelheit? Das Leben deiner Hände wird nicht vergessen. b:

a: Der Ort für die Stürme. Keine Art von Verzeihung. Wohin? b:

[a. What darkness? The life of your hands will not forget.

b.

a. The place for the storms. No form of forgiveness. Where to?

b.

Where the substance of a sentence is reversed in the manner of a neatly executed somersault Waterhouse leads the reader to an intimation of an incredible, contentless saying, like a meta-language in which the simultaneous presence of all options renders otiose the choice of a single one of them. If the 'you' is addressed with confusing alternatives (in the manner of 'Wir sind glücklich. Sind wir glücklich?' [We are happy. Are we happy?] ${ }^{42}$ ), then language scepticism has become so deeply rooted that a new consensus between author and reader is needed to make possible a meeting between them, to take place on the basis of mutual mistrust and in the realm of the signifier that has been freed from the duty to signify. This kind of language criticism is unmistakable in a single-line poem from passim:

\section{Sprache 2}

Glauben Sie mir das Wort Blume? ${ }^{43}$

[Language 2: Do you believe me when I say the word flower?]

In the collection $E 7 I$, published in 1996, which consists of Waterhouse's idiosyncratic diary from a journey into war-torn former Yugoslavia, the lack of substance in questioning that has already been demonstrated is supplemented by a clear insight into how the last vestiges of value in questioning are degraded by the language of the media and the unreflective conventions of everyday communication into meaningless collections of unimportant information. In the face of the destructiveness of the war and the sufferings of the people directly affected the poet has an apprehension of how deeply questionable questioning is, as long as an objectivity is imagined whose only purpose is to hide the profound ignorance of the questioner. Waterhouse's poetics of voices achieves its most coherent expression here, where the act of writing coincides with the sympathetic listening to suffering voices, which sound out symbolically for all the sufferings of mankind. This is a sympathy far removed from tearful or passive sharing of misery, and one where the words of the sufferers are offered a silent space beyond all the rhetoric of sympathy, a space in which the poet not only has his own speechless

\footnotetext{
41 Waterhouse, passim, p. 100.

42 Waterhouse, Menz, p. 42.

43 Waterhouse, passim, p. 86. See in this context the brilliant essay by Hermann Korte: "Mit keinem Wort ein Wissen". Die kurzen Gedichte von Peter Waterhouse', Text + Kritik, 137 (1998), $4^{\mathrm{I}-52 .}$
} 
amazement appear but also challenges readers to fill the blank space typographically surrounding the brief utterances of those affected by war with the determined courage of their own convictions in the practice of their own interpersonal relations:

Was erwarten Sie sich?

«-

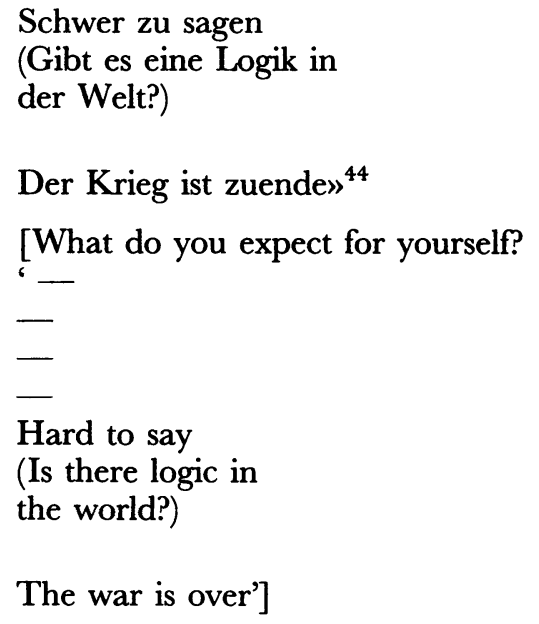

${ }^{44}$ Peter Waterhouse, E 7r. Mitschrift aus Bihać und Krajina (Salzburg and Vienna, 1996), n.p.. 